\title{
A new country record and additions to the moss floras of Luzon and Mindanao islands, Philippines
}

\author{
Virgilio C. Linis \\ Department of Biology, College of Science, De La Salle University, Manila 1004 Philippines \\ virgiliolinis@gmail.com; virgilio.linis@dlsu.edu.ph
}

\begin{abstract}
One new record and new locality information for fifteen species of Philippine mosses are reported for Luzon and Mindanao Islands. Of these Physcomitrium eurystomum Sendtn. and Syrrhopodon albidus Thwaites \& Mitt. are new records for Luzon Island. The former taxon is also new for the Philippines. The remaining taxa: Barbella convolvens (Mitt.) Broth., Chaetomitrium pseudoelongatum Broth., Clastobryum caudatum M.Fleisch., Distichophyllum osterwaldii M.Fleisch., D. tortile Dozy \& Molk. ex Bosch \& Sande Lac., Gemmabryum exile (Dozy \& Molk.) J.R.Spence \& H.P.Ramsay, Macrothamnium hylocomioides M.Fleisch., Meteoriella soluta (Mitt.) S.Okamura, Plagiomnium integrum (Bosch \& Sande Lac.) T.J.Kop., Racomitrium subsecundum (Hook. \& Grev.) Mitt. \& Wilson, Rhamphidium dixonii E.B.Bartram, Schlotheimia macgregorii Broth. \& Geh., Scopelophila cataractae (Mitt.) Broth., and Taxithelium planissimum Broth. are new records for Mindanao Island.
\end{abstract}

\section{Introduction}

The last twenty years have witnessed a series of new publications dealing with the Philippine moss flora not only for Luzon (Linis and Tan 2008, 2010, 2013, Linis 2014) but also for Mindanao (Azuelo et al. 2015, Tan and Shevock 2014, 2015) and its adjacent islands, Camiguin, for example (Linis 2010). The latest information provided by these new publications have increased our knowledge about the moss flora of these islands, and there are now 645 species in 229 genera known from Luzon Island and 362 species in 152 genera known for the island of Mindanao.

Continued studies of the many unidentified bryological collections kept at the Philippine National Herbarium $(\mathrm{PNH})$ and the recent bryological explorations conducted by the author in Luzon and Mindanao Islands, however, have resulted in new locality information of two moss taxa for Luzon and fourteen moss taxa for Mindanao islands. With the addition of these new records, Luzon now has a moss flora consisting of 647 species in 230 genera while the current moss flora of Mindanao Island now has 376 species in 156 genera.

One Philippine new record and fifteen noteworthy new moss records for Luzon and Mindanao Islands are reported below. These new records have been verified with recent publications such as Azuelo et al. (2015), Linis (2004, 2006, 2009, 2010, 2014), Linis and Tan (2008, 2010, 2013), Lubos (2007), Tan and Iwatsuki (1991), Tan et al. (2000) and Tan and Shevock $(2014,2015)$. Voucher specimens of these novelties are kept in the PNH with some duplicates distributed to other herbaria such as De La Salle University(DLSUH) in Manila, Philippines and the Singapore Botanic Gardens (SING). Listing of species are in alphabetical order for ease of reference. 


\section{Philippine new records for Luzon Island}

Physcomitrium eurystomum Sendtn. Denkschriften der Bayerischen Botanischen Gesellschaft in Regensburg 3: 142. 1841. (Funariaceae)

This widely distributed moss taxon from the north temperate region is reported here not only as a new record for Luzon island but also for the entire Philippine archipelago. Physcomitrium eurystomum Sendtn. is characterized by solitary plants with erect- cup-shaped capsules (Fig. 1). Like any species of Physcomitrium, this plant is rather small and are locally found on mud on the edges of reservoir and agricultural lands. This finding of P. eurystomum in Luzon, is the third in the country for this genus along with P. japonicum (Hedw.) Mitt. from Negros Island (Tan and Iwatsuki 1991) and P. sphaericum (C.Ludw.) Fürnr. from the Bicol Peninsula, also from island of Luzon (Linis 2014).

According to Enroth (1991), Physcomitrium eurystomum appears to be closely related to P. japonicum. However, P. eurystomum has distinctive collenchymatous exothecial cells on its young capsules while its spores are rather blackish-brown in color and densely spinulose (Ochi 1968). Physomitrium eurystomum is quite similar to $P$. sphaericum in general appearance. However, the former has longer seta $(9-10 \mathrm{~mm})$ and larger spores (c. $30 \mu \mathrm{m}$ in diameter) compared to P. sphaericum which has shorter seta (below $2 \mathrm{~mm}$ ) and smaller spores (c. $25 \mu \mathrm{m}$ in diameter) (Eddy 1996).

Extra-Philippine Distribution: Widely distributed in the Old World of the northern hemisphere (Ochi 1968, Corely et al. 1981, Noguchi and Iwatsuki 1988, Enroth, 1991, Ignatov and Afonina 1992, Eddy 1996). IntraPhilippine Distribution: New to the Philippines.

Specimens examined: Mount Santo Tomas, Municipality of Tuba, Benguet province, Luzon Island, Philippines, on moist soil bank beside agricultural field, 1917 masl, $16^{\circ} 21.5^{\prime} \mathrm{N} 120^{\circ} 33.8^{\prime} \mathrm{E}, 15 \mathrm{Nov} 2017$, V.C. Linis 5187-17 (PNH; DLSUH)
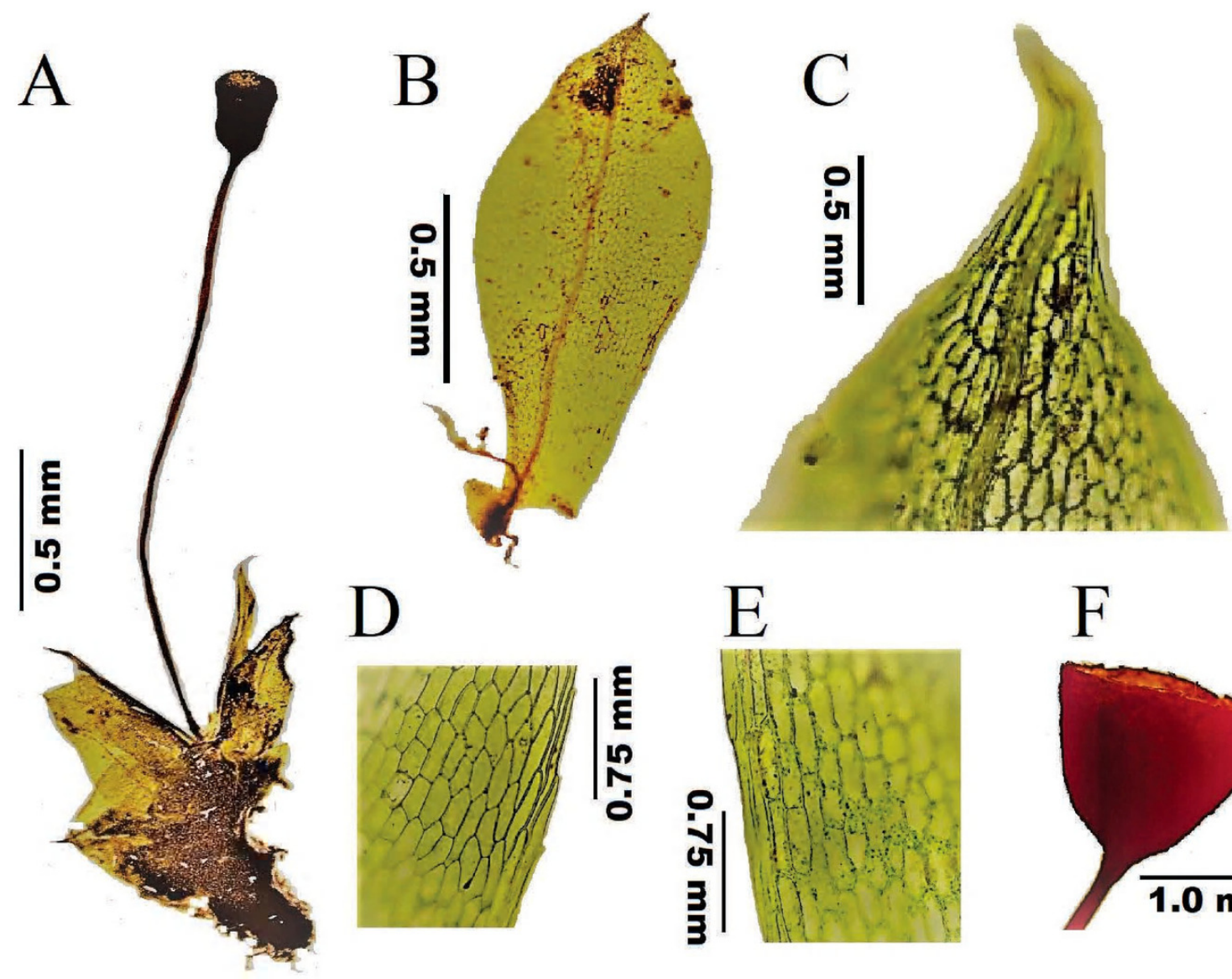
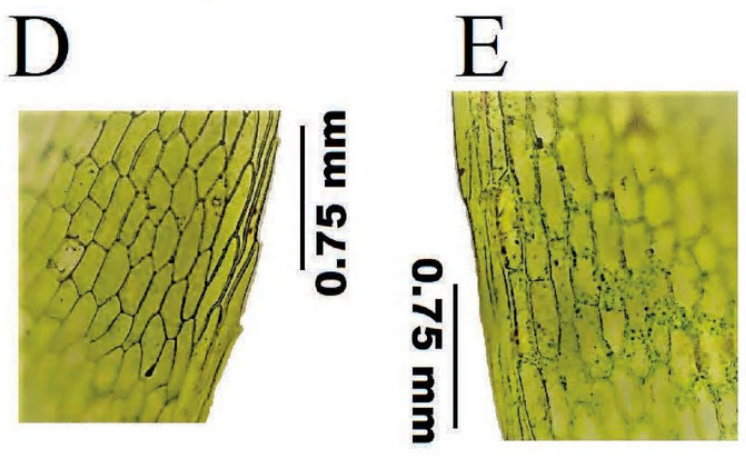

Fig. 1. Physcomitrium eurystomum Sendtn. A. habit; B. leaf displaying shape and apex; C. close-up of leaf apex with apiculate tip; D. leaf margin near leaf apex; E. leaf margin at mid-leaf; F. cup-shaped capsule. (Figure developed by V. C. Linis). 
Syrrhopodon albidus Thwaites \& Mitt. Journal of the Linnean Society, Botany 13: 298. 1873. (Calymperaceae)

This is the first confirmed report of Syrrhopodon albidus in Luzon Island. According to Tan and Iwatsuki (1991), the occurrence of this taxon in the Philippines was reported by Mohamed and Reese (1985), Reese and Mohamed (1985) and Orbán and Reese (1990) but none of these provided locality information. Another taxon, S. prolifer Schwägr., treated by Tan and Iwatsuki (1991) as distinct from S. albidus, was reported to occur in Mindanao. Orbán and Reese (1990) merged S. prolifer and S. albidus under a new combination, S. prolifer var. albidus to include all Sri Lankan, Malesian up to the Oceanian populations of this complex. This, too was mentioned to occur in the Philippines by Orbán and Reese (1990) but did not cited the taxon's exact location. Ellis (2005), having altered the status quo of several Old World taxa included within the S. prolifer complex, reinstated S. prolifer var. albidus at the level of species as S. albidus.

Syrrhopodon albidus, like other former varieties of the S. prolifer complex that have now been reinstated or recognized as separate taxa (Ellis 2003, 2005), are commonly found with neither sporophytes nor gemmae. Furthermore, all these taxa have very short stems that contribute to their "stemless" appearances, mostly corticolous and with leaves bordered all around by elongate, hyaline cells. However, specimens of S. albidus have cells in the chlorophyllose lamina with one or two low papillae which is very distinctive from the chlorophyllose cells of other taxa with either multiple low papillae or tall multifid papillae. In the field, plants of S. albidus are like those of S. tosaensis Cardot distributed from Japan, southeastern China to Thailand but differ having generally larger cells in the chlorophyllose lamina. In addition, the leaves of S. albidus have margins entire at the shoulders, in contrast to the frequently toothed leaf shoulders of S. tosaensis.

Extra-Philippine Distribution: Pantropical (Eddy 1988, Orbán and Reese 1990). Intra-Philippine Distribution: Mindanao (Tixier 1978, Tan and Iwatsuki, 1991).

Specimen examined: North slope of Mount Isarog, Province of Camarines Sur, Luzon Island, on trunk of tree fern, 14 May 1991, Cabalguinto 2139 (PNH).

\section{New moss records for Mindanao Island}

\section{Barbella convolvens (Mitt.) Broth. Die Natürlichen Pflanzenfamilien I(3): 824. 1906. (Pterobryaceae)}

This Himalayan-East Malesian taxon was earlier reported by Tan \& Iwatsuki (1991) from Mount Talinis, Negros island in the Philippines. Fertile of plants of this taxon are distinguished from other members of Meteoriaceae by having scabrous seta with similar lengths as its capsules (Noguchi 1976). Among its congeners, Barbella convolvens differs by having filiform stems with complanate branches and capsules with apophysis at the base. Its branch leaves are widely spreading, oblong, subulate at apices which become undulate along mid-margins.

Extra-Philippine Distribution: Ceylon, India, Himalayas, Thailand, Borneo, Sumatra, Java, and Sulawesi (Noguchi 1976). Intra-Philippine Distribution: Negros (Tan and Iwatsuki 1991).

Specimen examined: Mount Hamiguitan, Davao Oriental province, Mindanao Island, on tree branches, Transitional lowland forest, 850 masl, 19 Apr 2007, V.C. Linis 2418-07 (PNH).

Chaetomitrium pseudoelongatum Broth. Monsunia, Beiträge zur Kenntniss der Vegetation des Süd- und Ostasiatischen Monsungebietes 1: 47. 1899. (Hookeriaceae)

Both Brotherus (1900) and Bartram (1939) reported Chaetomitrium pseudoelongatum as endemic to the island of Tawi-Tawi. This gathering extends further its range to Mindanao Island.

Apart from Chaetomitrium pseudoelongatum Broth., there are six other taxa of Chaetomitrium reported in Malesia having blunt or truncate branch leaves, namely: C. darnaedii H.Akiy. \& M.Suleim.; C. elmeri Broth.; C. elongatum (Dozy \& Molk.) Dozy \& Molk.; C. perarmatum Broth.; C. schofieldii Tan \& Robins.; and C. warburgii Broth. Among these six taxa, C. darnaedii, C. elmeri and C. perarmatum are most distinct from C. pseudoelongatum since these taxa have lamina cells spinose or tuberculate on dorsal surfaces of their leaves. On the other hand, smooth leaf lamina cells are shared by C. pseudoelongatum with C. elongatum, C. schofieldii and C. warburgii (Tan and Robinson 1990). However, C. schofieldii has branches with seriate foliations and smooth seta (c. $10 \mathrm{~mm}$ long) while the three other taxa, C. pseudoelongatum, C. elongatum and C. warburgii, have variously foliated branches and weakly papillose seta. Both $C$. elongatum and C. warburgii have entire or crenulate upper leaf margins which contrast with the sharply serrate upper leaf margins of C. pseudoelongatum (Akiyama and Suleiman 2001).

Extra-Philippine Distribution: Endemic to the Philippines (Tan and Iwatsuki 1991, Akiyama and Suleiman 2001). Intra-Philippine Distribution: Tawi-Tawi (Tan and Iwatsuki 1991). 
Specimens examined: Cordillera Central Range, Sitio Magantol, Barangay Busdi, Malaybalay City, Bukidnon province, Mindanao island, on stem of small tree in forest, Secondary lowland forest, 850 masl, 17 May 2008, Linis 3553-08 (PNH); Cordillera Central Range, Sitio Magantol, Barangay Busdi, Malaybalay City, Bukidnon province, Mindanao Island, high on small branches, almost pendulous; Transitional lowland forest, 1020 masl, 17 May 2008, Linis 3610-08 (PNH).

Clastobryum caudatum M.Fleisch. Die Musci der Flora von Buitenzorg 4: 1190, 196 f. 13. 1923. (Sematophyllaceae)

The taxon, Clastobryum caudatum M.Fleisch. consists of small epiphytic plants with erect-spreading leaves with filamentous, brood, bodies borne on attenuated branches (Tixier 1969, 1977, He 2005). It is most similar to C. papillosum R.S.Williams and C. indicum (Dozy \& Molk.) Dozy \& Molk. for having ovate-lanceolate leaves with alar cells in one rank at the base. However, C. papillosum have leaves with serrate apices and papillose leaf lamina cells with moderately thick walls. As in C. caudatum, the leaf apices of $C$. indicum are never serrate but tend to be gradually acute to short-acuminate in shapes. The leaf apices of C. caudatum are long-acuminate (Tan and Buck 1989).

Clastobryum caudatum can be confused with Clastrobryophilum bogoricum (Bosch \& Sande Lac.) M.Fleisch. with records in Luzon and Sibuyan islands (Tan and Iwatsuki 1991) The leaves of C. caudatum, however, tend to have wide bases which abruptly narrow into long acuminate apices. Furthermore, the leaf margins of C. caudatum are often recurved, at least one side, toward the upper halves of the leaves, features which are not normally observed among the narrowly linear-lanceolate leaves of Clastrobryophilum bogoricum.

Extra-Philippine Distribution: Java (Fleischer 1923) and Thailand (Dixon 1932). Intra-Philippine Distribution: Mindoro (Tan and Iwatsuki 1991, Linis 2009).

Specimens examined: Cordillera Central Range, Sitio Magantol, Barangay Busdi, Malaybalay City, Bukidnon province, Mindanao Island, on base of bamboo clump, Agricultural land, 550 masl, 15 May 2008, V.C. Linis 3486-08 (PNH); Cordillera Central Range, Sitio Magantol, Barangay Busdi, Malaybalay City, Bukidnon province, Mindanao Island, on tree branch, Transitional lowland forest, 1020 masl, 17 May 2008, V.C. Linis 3599-08 (PNH).

Distichophyllum osterwaldii M.Fleisch. Die Musci der Flora von Buitenzorg 3: 994.170 a-g. 1908. (Hookeriaceae)

This taxon is the largest among the Distichophyllum so far reported from the Philippines (Tan and Robinson 1990). Its large, spathulate leaves with an undifferentiated upper leaf border (He 2002) set the taxon apart from the rest of the Philippine Distichophyllum species. Another new Mindanao record of Distichophyllum, D. tortile Dozy \& Molk. ex Bosch \& Sande Lac., reported below, also has comparably large leaves but its leaf cells are large and relatively homogenous in the upper half of the leaf.

Extra-Philippine Distribution: China (Lin and Tan 1995), Japan (Ryukyu islands), Taiwan, Borneo and Java (Noguchi et al. 1991). Intra-Philippine Distribution: Luzon, Mindoro, Negros and Leyte (Tan and Iwatsuki, 1991).

Specimen examined: Cordillera Central Range, Sitio Magantol, Barangay Busdi, Malaybalay City, Bukidnon province, Mindanao, on small tree stems; Transitional lowland forest, 1120 masl, 15 May 2008, V.C. Linis 363408 (PNH).

Distichophyllum tortile Dozy \& Molk. ex Bosch \& Sande Lac. Bryologia Javanica 2:27.152.1862. (Hookeriaceae)

This rather uncommon but distinctive taxon can attain the size of Distichophyllum osterwaldii M.Fleisch. (Tan and Robinson 1990). However, plants of $D$. tortile have large, homogenous thin-walled lamina cells (c. $20 \mu \mathrm{m}$ in diameter) from margins to costa in the upper half of the leaves (He 2002). D. osterwaldii has leaf lamina cells similar in size but are distinctively smaller towards the margins compared to those found near the costa (paracostal cells). The only other Distichophyllum taxon with similar homogenous leaf lamina cells is D. cucullatum E.B.Bartram, also reported to occur in Mindanao (Tan and Iwatsuki 1991). However, D. cucullatum has cucullate leaf apices which are generally round or ending in a very short mucro. In contrast, the leaf apices of $D$. tortile are not cucullate which are generally obtuse and apiculate in forms.

Extra-Philippine Distribution: Indochina, Malay Peninsula, Borneo and Java (Tan and Robinson 1990). Intra-Philippine Distribution: Luzon (Tan and Iwatsuki 1991); Mindoro (Linis 2009).

Specimens examined: Mount Timpoong, Camiguin province, Camiguin Island, on wet rocks, Montane forest, 1250 masl, 21 May 2017, V.C. Linis 2536-07 (PNH), Cordillera Central Range, Sitio Magantol, Barangay Busdi, Malaybalay City, Bukidnon province, Mindanao, on moist rock; Transitional lowland forest, 1120 masl, 
17 May 2008, V.C. Linis 3623-08 (PNH); Mount Balatukan, Cordillera Central Range, Misamis Oriental province, Mindanao, on wet boulders adjacent to creek, Lower montane forest, Transitional lowland forest, 1981 masl, $08^{\circ} 43.8^{\prime} \mathrm{N} 125^{\circ} 00.2^{\prime} \mathrm{E}, 06 \mathrm{Nov} 2010$, V.C. Linis $4628-10$ (PNH)

Gemmabryum exile (Dozy \& Molk.) J.R.Spence \& H.P.Ramsay. Phytologia 87(2): 67. 2005. (Bryaceae)

Spence (2005) transferred Brachymenium exile (Dozy \& Molk.) Bosch \& Sande Lac. under the new genus Gemmabryum as Gemmabryum exile (Dozy \& Molk.) J.R.Spence \& H.P.Ramsay. Distinctively small and glossy, G. exile is one of the smaller Gemmabryum species which can be easily identified in the field by its neat, stringlike barren stems and erect ovoid capsule with distinct rugose apophysis (Eddy 1996). Gemmabryum exile is quite common in northern Luzon, where it is found on soil, rocks and walls in both natural and anthropogenic habitats over a wide altitudinal range. The more widespread G. coronatum which can be found in similar habitats, also has rugose apophysis. However, the capsule of G. coronatum is always short-cylindrical and pendulous. This collection of G. exile is new to Mindanao island.

Extra-Philippine Distribution: Pantropical and subtropical (Eddy 1996). Intra-Philippine Distribution: Luzon and Negros (Tan and Iwatsuki 1991).

Specimens examined: Mount Balatukan, Cordillera Central Range, Misamis Oriental province, Mindanao, on exposed moist thin soil, Transitional lowland forest, 1432 masl, $08^{\circ} 43.9^{\prime} \mathrm{N} 125^{\circ} 00.3^{\prime} \mathrm{E}, 06 \mathrm{Nov} 2010$, V.C. Linis 4499-10 (PNH); Mount Balatukan, Cordillera Central Range, Misamis Oriental province, Mindanao, on exposed soil, Transitional lowland forest, 1432 masl, $08^{\circ} 43.9^{\prime} \mathrm{N} 125^{\circ} 00.3^{\prime} \mathrm{E}, 06 \mathrm{Nov} 2010$, V.C. Linis 4514-10 (PNH).

Macrothamnium hylocomioides M.Fleisch. Nova Guinea 2: 125.34A. 1914. (Hylocomiaceae)

In the field, Macrothamnium hylocomioides M.Fleisch. is essentially indistinguishable from the more widespread M. macrocarpum (Reinw. \& Hornsch.) M.Fleisch. in terms of size and overall macroscopic appearance. According to Noguchi (1972), M. hylocomioides can be recognized from M. macrocarpum by its stem leaves which are reniform, not or slightly decurrent, with abruptly pointed and recurved leaf apices (Koponen and Norris 1985). On the other hand, M. macrocarpum has broadly cordate stem leaves which are distinctly decurrent and acute at the apex. Rohrer (1985) stated that the stem leaves of M. hylocomioides are wider in proportion to its length (0.7-1.0: 1$)$ while those of the M. macrocarpum are longer than wide (1.0-1.3). Before this current report about the occurrence of this taxon in Mindanao, M. hylocomioides was only known from Luzon in the Philippines.

Extra-Philippine Distribution: New Guinea (Noguchi 1972, Koponen and Norris 1985). Intra-Philippine Distribution: Luzon (Tan and Iwatsuki 1991).

Specimens examined: Mount Apo, Cordillera Central Range, Davao del Sur province, Mindanao, on decaying wood, Upper montane forest, 2718 masl, 06 $59.693^{\prime}$ N 125 16.204' E, 11 Feb 2011, V.C. Linis 4996-11 (PNH); Mount Apo, Cordillera Central Range, Davao del Sur province, Mindanao, on lower tree trunk, Upper montane forest, 2900 masl, $06^{\circ} 59.693^{\prime}$ N $125^{\circ} 16.204^{\prime}$ E, 12 February 2011, V.C. Linis 5014-11 (PNH).

Meteoriella soluta (Mitt.) S.Okamura. Journal of the College of Science, Imperial University of Tokyo 36(7): 18. 1915. (Hylocomiaceae)

For many years, Meteoriella soluta (Mitt.) S.Okamura was known only in northern Luzon (Tan and Iwatsuki 1991) which is geographically close to Eastern Asia. However, this paper now reports that this species is also present in Mindanao. This indicates that M. soluta should not belong to the Eastern endemic taxon but should be treated under another phytogeographical category. Additional searches of this taxon south of Mindanao may reveal that this species has a broader range than was previously thought. A good illustration of Meteoriella soluta is shown in Manuel (1976).

Study by Wang et al. (2010) using morphological and molecular data placed M. soluta under the family of Hylocomiaceae, even though it has been traditionally classified either under family Pterobryaceae or Meteoriaceae. Within the Hylocomiaceae, M. soluta is phylogenetically closest to the genus Leoskeobryum. While M. soluta shares some features with species of Meteoriaceae and Pterobryaceae such as pendent shoots, the lack of well-developed central strands in the stem, erect capsules and reduced peristomes, these features are most likely to be products of convergent evolution in epiphytic habitats (Hedenäs 2001, Huttunen et al. 2004, Quandt and Huttunen 2004).

Extra-Philippine Distribution: Sikkim, Bhutan, Assam, China, North Vietnam, Taiwan and Japan (Koponen 1972, 1981, Manuel 1976). Intra-Philippine Distribution: Luzon (Tan and Iwatsuki 1991). 
Specimen examined: Mount Balatukan, Cordillera Central Range, Misamis Oriental province, Mindanao Island, pendulous on tree branches, Upper montane forest, $08^{\circ} 44.9^{\prime} \mathrm{N} 124^{\circ} 59.5^{\prime} \mathrm{E}, 06 \mathrm{Nov} 2010,2300$ masl, V.C. Linis 4645-10 (PNH).

Plagiomnium integrum (Bosch \& Sande Lac.) T.J.Kop. Hikobia 6: 57. 1971. (Mniaceae)

This is the second species of Plagiomnium reported for Mindanao Island and in most respects it is like the more common P. succulentum. On the average, however, $P$. integrum is smaller than the latter in all its parts. In addition, the leaf border of $P$. integrum, even in is weaker states, is more strongly developed than in P. succulentum, often yellowish, with up to 5 cells wide below mid-leaf compared to the leaf border of P. succulentum which are only 1-2 cells wide throughout (Koponen 1981). Plagiomnium integrum is also definitely separated from P. succulentum by its smaller, slightly thickened and sometimes with pitted walls, leaf lamina cells, $25-35 \mu \mathrm{m}$ in its longest diameter. The thinner leaf lamina cells of $P$. succulentum can reach up to $70 \mu \mathrm{m}$ or more in diameter and are therefore, twice as large as those of P. integrum.

Extra-Philippine Distribution: India, Nepal, Burma, Taiwan, Borneo, Indonesia (Koponen 1972, 1981). Intra-Philippine Distribution: Luzon (Tan and Iwatsuki 1991).

Specimen examined: Vicinity of Lake Agco, Mt. Apo (West slope), Kidapawan City, North Cotabato province, Mindanao, on wet rocks near brook, Secondary lower montane forest, 1200 masl, $07^{\circ} 01.142^{\prime} \mathrm{N} 125^{\circ} 13.388^{\prime} \mathrm{E}$, 09 Feb 2011, V.C. Linis 4818-11 (PNH).

Racomitrium subsecundum (Hook. \& Grev.) Mitt. \& Wilson. Hooker's Journal of Botany and Kew Garden Miscellany 9: 324. 1857. (Grimmiaceae)

Reports of Racomitrium subsecundum (Hook. \& Grev.) Mitt. \& Wilson in the Philippines were mainly confined to Luzon Island (Tan and Iwatsuki 1991). This collection extends the distribution range of $R$. subsecundum and the genus to Mindanao Island. R. subsecundum is endemic to Malesia (Eddy 1996).

Characteristic of its genus, the leaf lamina cells of R. subsecundum are long and narrow with thin transverse walls but with strongly thickened and nodulose longitudinal walls. Known to be variable in its size and growth forms, the short, dentate hair points found in its muticous leaves will easily distinguished R. subsecundum from R. fasciculare (Schrad. ex Hedw.) Brid., the other Philippine species of Racomitrium.

Extra-Philippine Distribution: Known from India, Nepal, Sikkim, Bhutan, Sri Lanka, China, Taiwan, Borneo, Sumatra and Java in Asia, Papua New Guinea, southern Mexico, Guatemala and the Dominican Republic in Central America. Could also be found in South America. (Frisvoll 1988). Intra-Philippine Distribution: Luzon (Tan and Iwatsuki 1991).

Specimen examined: Vicinity of Lake Venado, Mt. Apo (West slope), North Cotabato province, Mindanao island, on tree trunk, Upper montane forest, 2377 masl, $10 \mathrm{Feb} 2011,07^{\circ} 00.263^{\prime} \mathrm{N} 125^{\circ} 16.088^{\prime} \mathrm{E}$, V.C. Linis 4927-11 (PNH).

\section{Rhamphidium dixonii E.B.Bartram. Philippine Journal of Science 68: 109. f. 129. 1939. (Ditrichaceae)}

The author's Mindanao collection is only the second known gathering of Rhamphidium dixonii E.B.Bartram. The species' original collection was from Canlaon Volcano where it grew terrestrially on deeply, shaded acid soils. Sterile R. dixonii can easily be mistaken for a Microdus Schimp. ex Besch. due to its growth habit. However, fertile plants of this taxon can be identified by the presence of 16 erect filiform, papillose processes to $200 \mu \mathrm{m}$ long in the peristomes.

The genus Rhamphidium is not very well understood at the present time. Its systematic position is obscure although it appears to combine Pottioid sporophytic features with that of a more Dicranoid gametophytic characteristics. True affinities of Rhamphidium need to be ascertain.

Extra-Philippine Distribution: Endemic to the Philippines (Bartram 1939, Eddy 1988, Tan and Iwatsuki 1991). Intra-Philippine Distribution: Negros (Tan and Iwatsuki 1991).

Specimen examined: Vicinity of Lake Venado, Mt. Apo (West slope), North Cotabato province, Mindanao island, on soil bank beside trail, Upper montane forest, 2377 masl, 10 Feb 2011, $07^{\circ} 00.263^{\prime} \mathrm{N} 125^{\circ} 16.088^{\prime} \mathrm{E}$, V.C. Linis 4928-11 (PNH).

Schlotheimia macgregorii Broth. \& Geh. Öfversigt af Finska Vetenskaps-Societetens Förhandlingar 40: 170. 1898. (Orthotrichaceae)

This is the second locality reported for Schlotheimia macgregorii Broth. \& Geh. in the Philippines. The first report for this taxon are from Mount Baloy in Panay Island (Linis and Tan 2010). The Mindanao plants of S. macgregorii Broth. \& Geh. are generally smaller and much slenderer than the more widespread S. wallisii 
C.Müll. The former can be identified with ease, when moist, with its conspicuous strongly recurved-squarrose leaves which are erect-spreading to patent in S. wallisii. In fertile plants of S. macgregorii, the squarrose-recurved perichaetial leaves are conspicuous, always projecting well above the normal leaves on female branches. Perichaetial leaves of S. emarginatopilosa Herzog, another Schlotheimia taxon reported in the Philippines, are similarly conspicuous but these leaves are erect instead of being squarrose-recurved.

Extra-Philippine Distribution: Sulawesi, Ceram, New Guinea (Eddy 1996). Intra-Philippine Distribution: Panay (Linis and Tan 2010).

Specimens examined: Mount Balatukan, Cordillera Central Range, Misamis Oriental province, Mindanao, on lower branch of medium-sized tree, Lower montane forest, 1981 masl, $08^{\circ} 43.8^{\prime} \mathrm{N} 125^{\circ} 00.2^{\prime} \mathrm{E}, 06 \mathrm{Nov} 2010$, V.C. Linis 4609-10 (PNH); Marbel River trail leading to Lake Venado, Mt. Apo (West slope), North Cotabato province, on tree branch, Transitional lowland forest, 1345 masl, $07^{\circ} 01.218^{\prime} \mathrm{N} 125^{\circ} 13.864^{\prime} \mathrm{E}, 10 \mathrm{Feb} 2011$, V.C. Linis 4915-11 (PNH); Mount Apo, Cordillera Central Range, North Cotabato province, Mindanao, on tree branch, Upper montane forest, 2900 masl, 06 59.693' N 125 16.204' E, 12 Feb 2011, V.C. Linis 5027-11 (PNH).

Scopelophila cataractae (Mitt.) Broth. Die Natürlichen Pflanzenfamilien I(3): 436. 1902. (Pottiaceae)

This moss taxon is almost similar in habit to Scopelophila lingulata (Spruce) Spruce, also reported to occur in Mindanao. In its encountered form, S. cataractae appears to resemble species of Anoectangium bearing similar leaf outlines and tomentose stems. The leaves of the latter genus, however, have opaque, papillose leaves with contrasting pellucid costae. Scopelophila cataractae differs from S. lingulata by the presence of a small hyaline leaf base with differentiated margins composed of short, rectangular cells with firm calls. This hyaline leaf base is more extensive in S. lingulata which lacks the marginal bands of small cells that characterize S. cataractae.

Extra-Philippine Distribution: North America, China, Japan, Korea, Bhutan, India, Nepal, Indonesia and Papua New Guinea (Norris and Koponen 1989, Eddy 1990). Intra-Philippine Distribution: Luzon (Tan and Iwatsuki 1991).

Specimen examined: Mount Balatukan, Cordillera Central Range, Misamis Oriental province, Mindanao, on exposed mineral soils, Transitional lowland forest, 1432 masl, $08^{\circ} 43.9^{\prime} \mathrm{N} 125^{\circ} 00.3^{\prime} \mathrm{E}, 06 \mathrm{Nov} 2010$, V.C. Linis 4519-10 (PNH).

Taxithelium planissimum Broth. Hedwigia 50: 141. 1910. (Pylaisiadelphaceae)

The former Philippine endemic Taxithelium ramicola Broth., along with the Papuan taxon, T. wewakense E.B.Bartram are now treated as synonyms of T. planissimum Broth. (Camara 2011) which turns out to be more widespread than was previously thought. Before the report of this taxon in Mindanao, T. planissimum is known only in Luzon and Polillo Islands (Tan and Iwatsuki 1991).

Taxithelium planissimum slightly resemble the Malesian endemic T. isocladum (Bosch \& Sande Lac.) Renauld \& Cardot in terms of its size, leaf shapes and the absence of well-developed alar cells. The two taxa, however, differ in the cells found apices of their perichaetial leaves being smooth in T. planissimum and pluripapillose in T. isocladum. In addition, the opercula of T. planissimum are distinctly long-rostrate while that of the $T$. isocladum are conic to conic-rostrate. The seta of T. planissimum is longer compared to T. isocladum.

Extra-Philippine Distribution: Philippines (Brotherus 1913, Tan and Iwatsuki 1991), Gabon, Indonesia, Malaysia, Sri Lanka, Vietnam and New Guinea (Camara 2011). Intra-Philippine Distribution: Luzon (Brotherus 1913, Tan and Iwatsuki 1991) and Polillo (Tan and Iwatsuki 1991).

Specimen examined: Cordillera Central Range, Sitio Magantol, Barangay Busdi, Malaybalay City, Bukidnon province, Mindanao island, on small fallen tree branch, Transitional lowland forest, 1020 masl, 17 May 2008, V.C. Linis 3603-08 (PNH).

\section{Acknowledgements}

I am extremely grateful to the staff of the Philippine National Herbarium (PNH) for allowing access to the bryophyte collections. I am thankful to De La Salle University-Manila for allowing me to use their photomicroscopes to take digital images of Physcomitrium eurystomum. I am grateful to Niels Klazenga and the late Elizabeth Brown for organising access to the bryophyte collections held at the National Herbarium Melbourne, Royal Botanic Gardens, Victoria and the National Herbarium Sydney, Royal Botanic Gardens, New South Wales, respectively. Special thanks to the anonymous reviewer who made several corrections that I have incorporated into the paper. 


\section{References}

Akiyama H, Suleiman M (2001) Taxonomical notes on the genus Chaetomitrium (Hookeriaceae, Musci). Botanical Bulletin of Academia Sinica 32: 37-311.

Azuelo AG, Tan BC, Shevock JR, Manual A, Yorong A, Sariana L (2015) Mosses new for Mindanao island, Republic of the Philippines. Proceedings of the California Academy of Sciences 62: 127-134.

Bartram EB (1939) Mosses of the Philippines. Philippine Journal of Science 68: 1-423.

Brotherus VF (1913) Contributions to the bryological flora of the Philippines IV. Philippine Journal of Science $8 \mathrm{c}$ (Bot.): 65-98.

Camara PEAS (2011) A re-circumscription of the moss genus Taxithelium (Pylaisiadelphaceae) with a taxonomic revision of subgenus Vernieri. Systematic Botany 36: 7-21.

Corley MFV, Crundwell AC, Düll R, Hill MO, Smith AJE (1981). Mosses of Europe and the Azores: an annotated list of species, with synonyms from the recent literature. Journal of Bryology 11: 609-689.

Dixon HN (1932) On the moss flora of Siam. Journal of the Siam Society, Natural History Supplement. 9: 1-51.

Eddy A (1988) A handbook of Malesian mosses. 1. Sphagnales to Dicranales. British Museum (Natural History) London.

Eddy A (1990) A handbook of Malesian mosses. 2. Leucobryaceae to Buxbaumiaceae. British Museum (Natural History): London.

Eddy A (1996) A handbook of Malesian mosses. 3. Splachnobryaceae to Leptostomataceae. British Museum (Natural History): London.

Ellis, LT (2003) A revised synonymy for Syrrhopodon trachyphyllus (Calymperaceae, Musci) and some related Old World taxa. Systematics and Biodiversity 1:159-172.

Ellis, LT (2005) A revision of some old world moss taxa in the Syrrhopodon prolifer complex (Musci: Calymperaceae), and a new species from Malawi. Systematics and Biodiversity 3(2): 159-178.

Enroth A (1991) Bryophyte flora of the Huon Peninsula, Papua New Guinea. XLIII. Funariaceae (Musci). Acta Botanica Fennica 143: 57-69.

Fleischer M (1923) Die Musci der Flora von Buitenzorg. Volume 4, EJ Brill, Leiden.

Frisvoll AA (1988) A taxonomic revision of the Racomitrium heterostichum group (Bryophyta, Grimmiales) in N. and C. America, N. Africa, Europe and Asia. Gunneria 59: 5-289.

He S (2002) Moss flora of China (Volume 6, Hookeriaceae-Thuidiaceae), Science Press (Beijing, New York) and Missouri Botanical Garden Press (St. Louis), 219 pp.

He S (2005) Moss flora of China (Volume 8, Sematophyllaceae-Polytrichaceae), Science Press (Beijing, New York) and Missouri Botanical Garden Press (St. Louis), 385 pp.

Hedenäs L (2001) Environmental factors potentially affecting character states in pleurocarpous mosses. The Bryologist 104: 72-91.

Huttunen S., Ignatov MS, Müller K, Quandt D (2004) Phylogeny and evolution of epiphytism in the three moss families of Meteoriaceae, Brachytheciaceae and Lembophyllaceae. In: Molecular Systematics (ed. B. Goffinet, V. Hollowell \& R. Magill), Missouri Botanical Garden Press, St. Louis, pp. 328-361.

Ignatov MS, Afonina OM (eds.) (1992) Check-list of mosses of the former USSR. Arctoa 1: 1-85.

Koponen T (1972) The East Asiatic species of Plagiomnium sect. Rostrata (Bryophyta), Acta Botanica Fennica 97: 1-29.

Koponen T (1981) A synopsis of Mniaceae (Bryophyta). VI. Southeast Asian taxa. Acta Botanica Fennica 117: $1-117$.

Koponen T, Norris DH (1985) Bryophyte flora of the Huon Peninsula, Papua New Guinea. VIII. Hylocomiaceae and Rhytidiaceae (Musci). Acta Botanica Fennica 131: 53-61.

Lin, P-J, Tan BC, 1995. Contribution to the bryoflora of China (12): a taxonomic revision of Chinese Hookeriaceae (Musci). Harvard Papers on Botany 7: 25-68.

Linis VC (2004) A checklist of Mosses in Mount Arayat, Pampanga, Philippines, Journal of Tropical Biology. 3: 2-6.

Linis VC (2006) A Review of Intra-Philippine distribution pattern of Philippine mosses based on recent evidence of tectonic evolution of the archipelago: insights and problems. Banwa 3:31-64.

Linis VC (2009) Biogeography of Mindoro mosses, Blumea 54: 290-296.

Linis VC (2010) The moss flora of Camiguin island, Philippines and their floristic relations to adjacent islands in the archipelago, Telopea 12: 525-542.

Linis VC (2014) Biogeographical notes on the moss floras of Bicol Peninsula in Luzon and the Catanduanes Islands, The Philippines, Philippine Journal Science Special Issue. 142:119-133.

Linis VC, Tan BC (2008). Progress of studies on phytogeography and biodiversity of Philippine moss flora from 1991 to 2006, in: Mohamed MAH, Baki BB, Nasrulhaq-Boyce A, Lee PKY (eds). Bryology in the New Millennium, University of Malaya, Kuala Lumpur, pp. 13-22. 
Linis VC, Tan BC (2010) Eleven new records of Philippine mosses, in: Koponen, T, Piippo S, Reinikka E (eds.), Dr. Ming-Jou Lai Memorial Volume, Acta Bryolichenologica Asiatica 3: 35-100.

Linis VC, Tan BC (2013) Eight additional new records of Philippine mosses. Telopea 15: 45-49.

Lubos LC (2007) New records of Philippine moss flora from Mindanao island. Liceo Journal of Higher Education Research 5: 1-8.

Manuel MG (1976) A synopsis of Meteoriopsis (Bryopsida, Meteoriaceae), Bryologist 80: 584-599.

Mohamed MAH, Reese WD (1985) Syrrhopodon (Musci: Calymperaceae) in Malaysia and adjacent regions. Bryologist 88: 223-254.

Noguchi A (1972) A revision of the genus Macrothamnium (Musci), Kumamoto Journal of Science in Biology 11: 1-12.

Noguchi A (1976) A taxonomic revision of the family Meteoriaceae of Asia. Journal of the Hattori Botanical Laboratory 41: 231-257.

Noguchi A, Iwatsuki Z (1988) Illustrated moss flora of Japan (Part 2). Hattori Botanical Laboratory, Miyazaki, Japan, pp. 243-491, index.

Noguchi A, Iwatsuki Z, Yamaguchi T (1991) Illustrated Moss Flora of Japan (Part 4). Hattori Botanical Laboratory, Miyazaki, Japan, pp. 743-1012, indices i-ix.

Norris DH, Koponen T (1989) Bryophyte flora of the Huon Peninsula, Papua New Guinea. XXVIII. Pottiaceae (Musci). Acta Botanica Fennica 137: 81-138.

Ochi, H (1968) A revision of the family Funariaceae (Musci) in Japan and the adjacent regions. Japanese Journal of Botany 20: 1-34.

Orbán S, Reese WD (1990) Syrrhopodon prolifer (Musci: Calymperaceae): a world view. Bryologist 93: 438-444.

Quandt D, Huttunen S (2004) Evolution of pendant life forms in bryophytes. Journal of the. Hattori Botanical Laboratory 95: 207-217.

Reese WD, Mohamed MAH (1985) A synopsis of Calymperes (Musci: Calymperaceae) in Malaysia and adjacent regions. Bryologist 88: 98-109.

Rohrer JR (1985) A generic revision of the Hylocomiaceae. Journal of the Hattori Botanical Laboratory 59: 241-278.

Spence JR (2005) New genera and combination in the Bryaceae (Bryales, Musci) for Australia, Phytologia 87: $61-72$.

Tan BC, Buck WR (1989) A synoptic review of Philippine Sematophyllaceae with emphasis on Clastobryoideae and Hetrophylloideae (Musci). Journal of the Hattori Botanical Laboratory 60: 307-320.

Tan BC, Iwatsuki Z (1991) A new annotated Philippine moss checklist. Harvard Papers in Botany: 1- 63.

Tan BC, Robinson H (1990) A review of the Philippine Hookeriaceous taxa (Musci), Smithsonian Contribution to Botany 75: 1-41.

Tan BC, Lubos LC, Schwartz U (2000) New and biogeographically noteworthy records of Philippine mosses from Mindanao island. Tropical Biology 18: 27-37.

Tan BC, Shevock JR (2014) Noteworthy mosses collected from the 2014 expedition of CAS and CMU new to Mindanao island of the Philippines. Bryophyte Diversity \& Evolution 38: 22-30.

Tan BC, Shevock JR (2015) Species of Macromitrium (Orthotrichaceae) new to the Mindanao region and the Philippines with one species new to science. Proceedings of the California Academy of Sciences 64: 541-549.

Tixier P (1969) Dé Sematophyllaceis I. Essai de revision des Clastobryaceae de Luzon. Journal of the Hattori Botanical Laboratory 32: 21-34.

Tixier P (1977) Clastobryoidées et taxa apparentés. Revue Bryologique et Lichenologique 43: 397-464.

Tixier P (1978) Le genre Syrrhopodon Schwägr. (Calymperaceae) in Indo-Malaisie, Nova Hedwigia 29: 957-1023.

Wang Q, Jia J, Liu Y, Chen Z (2010). The systematic position of Meteoriella S. Okamura (Musci) based on molecular and morphological data. Taxon 59: 93-100. 


\section{$2 \mathrm{BHL}$ Biodiversity Heritage Library}

Linis, Virgilio C. 2018. "A new country record and additions to the moss floras of Luzon and Mindanao islands, Philippines." Telopea: Journal of plant systematics 21, 91-99. https://doi.org/10.7751/telopea12512.

View This Item Online: https://www.biodiversitylibrary.org/item/282223

DOI: https://doi.org/10.7751/telopea12512

Permalink: https://www.biodiversitylibrary.org/partpdf/305579

\section{Holding Institution}

The Royal Botanic Gardens and Domain Trust, New South Wales, Australia

\section{Sponsored by}

Atlas of Living Australia

\section{Copyright \& Reuse}

Copyright Status: In copyright. Digitized with the permission of the rights holder.

Rights Holder: The Royal Botanic Gardens and Domain Trust, New South Wales, Australia License: http://creativecommons.org/licenses/by-nc-sa/4.0/

Rights: http://biodiversitylibrary.org/permissions

This document was created from content at the Biodiversity Heritage Library, the world's largest open access digital library for biodiversity literature and archives. Visit BHL at https://www.biodiversitylibrary.org. 